\title{
The First Record of Nucleopolyhedrovirus Isolated from the Gypsy Moth, Lymantria dispar (Lepidoptera, Lymantriidae) in Turkey
}

Türkiye’de Lymantria dispar (Lepidoptera, Lymantriidae)'dan İzole Edilen Bir

Nükleopolihedrovirüs'ün İlk Kaydı

\author{
Mustafa Yaman¹, Çağrı Bekircan¹, Renate Radek², Andreas Linde ${ }^{3}$ \\ 'Department of Biology, Faculty of Sciences, Karadeniz Technical University, Trabzon, Turkey \\ 2Institute of Biology/Zoology, Free University of Berlin, Königin-Luise-Str. Berlin, Germany \\ ${ }^{3} \mathrm{FH}$ Eberswalde, Applied Ecology and Zoology, Alfred-Möller-Str. Eberswalde, Germany
}

\section{ABSTRACT}

Objective: The gypsy moth, Lymantria dispar L. (Lepidoptera, Lymantriidae) is a common pest of forests and fruit trees throughout the world. This insect is also a major serious pest in Turkey. Nowadays L. dispar can be managed by biological control methods especially, using entomopathogenic viruses. The aim of this study is to characterize entomopathogenic viruses and is the first record of nucleopolyhedrovirus isolated from the gypsy moth in Turkey.

Methods: PIBs obtained from infected larvae were measured and photographed using an Olympus BX51 microscope with a DP-25 digital camera and a DP2-BSW Soft Imaging System and examined with a Philips 208 electron microscope (TEM).

Results: The virus had the typical characteristics of nucleopolyhedroviruses. The dimension of the polyhedral inclusion bodies (PIBs) was $2.03 \pm 0.25 \mu \mathrm{m}$. PIBs varied in size from 1.65 to $2.21 \mu \mathrm{m}$ and were usually polygonal in shape. Virions in PIBs contained 1 to 8 nucleocapsids per virion. The size of the viral particles was $366.67 \pm 54.72(312-500) \times 42.95 \pm 6.12(30-47) \mathrm{nm}$.

Conclusion: The isolation and characterization of a pure isolate of Lymantria dispar multinucleopolyhedrovirus (LdMNPV-TR) from Turkey is presented for the first time. (Turkiye Parazitol Derg 2012; 36: 92-5)

Key Words: Lymantria dispar, nucleopolyhedrovirus, biological control

Received: 03.01 .2012

Accepted: 09.02.2012

\section{ÖZET}

Amaç: Çingene kelebeği; Lymantria dispar L. (Lepidoptera, Lymantriidae) tüm dünyada meyve ve orman ağaçlarının en bilindik zararlısıdır. Bu böcek Türkiye'de de en önemli zararlılardan biridir. Günümüzde L. dispar entomopatojenik virüslerin kullanımı gibi çeşitli biyolojik mücadele metotları ile control edilebilmektedir. Bu çalışmanın amacı çingene kelebeğinde tespit edilen ve Türkiye'de ilk kayıt olan, bir entomopatojenik nükleopolihedrovirüsün karakterizasyonunu gerçekleştirmektir.

Yöntemler: Enfekte larvalardan elde edilen PIB'ler; DP-25 dijital kameralı Olympus BX51 mikroskopu ve DP2-BSW Soft Imaging görüntüleme sistemi kullanılarak fotoğraflanıp ölçümleri gerçekleştirildi. Ayrıca Philips 208 elektron mikroskopu (TEM) kullanılarak PIB'ler üzerinde incelemeler yapıldı.

Bulgular: Bu virüs nükleopolihedrovirüs grubunun genel özelliklerini taşımaktadır. PIB'ler genelde poligonal şekilli, ortalama ölçüleri $2.03 \pm 0.25 \mu \mathrm{m}$ olup, ölçüler $1.65 \mu \mathrm{m}$ den $2.21 \mu \mathrm{m}$ 'e kadar değişkenlik göstermektedir. PIB'ler içerisindeki her bir virion 1-8 nükleokapsid

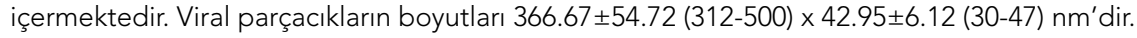

Sonuç: Türkiye'de ilk defa Lymantria dispar multinükleopolihedro virüsün (LdMNPV-TR) izolasyonu ve karakterizasyonu gerçekleştirildi. (Turkiye Parazitol Derg 2012; 36: 92-5)

Anahtar Sözcükler: Lymantria dispar, nükleopolihedrovirüs, biyolojik mücadele Geliş Tarihi: 03.01.2012

Kabul Tarihi: 09.02.2012

Address for Correspondence / Yazışma Adresi: Dr. Mustafa Yaman, Department of Biology, Faculty of Sciences, Karadeniz Technical University, Trabzon, Turkey Phone: +90 4623772586 E-mail: yaman@ktu.edu.tr doi:10.5152/tpd.2012.22 


\section{INTRODUCTION}

The gypsy moth, Lymantria dispar L. (Lepidoptera, Lymantriidae) is a common pest of forests and fruit trees throughout the world (1). This insect is also a major serious pest in Turkey. Most countries use chemical insecticides to control this pest. On the other hand, this control method has a big disadvantage because $L$. dispar and other pests can develop resistance to these chemicals. Nowadays, L. dispar can be managed by biological control methods especially using entomopathogenic viruses. Entomopathogenic viruses are host specific pathogens, so they do not harm other animals or plants except their host. Some isolates of this virus were recorded from different parts of the world. Although Asia is a potential source of new and interesting entomopathogenic virus strains (2), there is no record of $L$. dispar in Turkey. Some strains of nucleopolyhedrovirus isolated from different geographic localities may present better insecticidal activities, which make them more suitable for host control and show important differences in biological activity (3).

In the present study, the isolation and characterization of a novel isolate of Lymantria dispar multiple nucleopolyhedrovirus (LdMNPV) from Turkey are presented for the first time.

\section{METHODS}

\section{Collecting infected larvae of $L$. dispar}

Virus infected larvae of $L$. dispar were collected from natural populations of $L$. dispar. The infected larvae were transferred to collection tubes using sterile forceps. Collected samples were brought to the laboratory as soon as possible and stored at $-20^{\circ} \mathrm{C}(4)$.

The larvae were dissected in Ringer's solution and wet smears were examined under a microscope for identification of pathogens (5). When an infection was present, one part of the material was used for preparation of smears and another part was used for ultra-structural studies. The slides were air-dried and fixed with methanol for $10 \mathrm{~min}$. They were then washed with distilled water, stained for approximately ten hours in a freshly prepared $5 \%$ solution of Giemsa stain, washed in running tap water, air-dried, and re-examined under the microscope $(6,7)$. Detected fresh and stained PIBs were measured and photographed using an Olympus BX51 microscope with a DP-25 digital camera and a DP2-BSW Soft Imaging System.

For transmission electron microscope studies, portions of infected larvae were fixed in $2.5 \%$ glutaraldehyde in $0.1 \mathrm{M}$ cacodylate buffer ( $\mathrm{pH}$ 7.4) for 1-2 h, rinsed in cacodylate buffer, postfixed in reduced $\mathrm{OsO}_{4}$ according to Karnovsky (8) (a fresh 1:1 mixture of $2 \% \mathrm{OsO}_{4}$ and $3 \% \mathrm{~K}_{4}\left[\mathrm{Fe}\left(\mathrm{CN}_{6}\right)\right]$ ) for $1.5 \mathrm{~h}$, rinsed in cacodylate buffer, and dehydrated in ethanol prior to embedding in Spurr's resin (9). Thin sections were mounted on Pioloform-coated copper grids, which were then stained with saturated uranyl acetate and Reynolds' lead citrate (10). They were examined with a Philips 208 electron microscope (TEM).

\section{RESULTS}

The majority of dead larvae suspected of having the viral infection hang from oak branches attached with abdominal prolegs.
The viral inclusion bodies were easily observed in the hemolymph of the host insect and the infection showed the typical symptoms of nucleopolyhedroviruses, such as less active, darkbrown larvae with cuticula easily broken and releasing a brown fluid containing thousands of polyhedral inclusion bodies (PIBs) (3). Under the light microscope, large numbers of polyhedral inclusion bodies (PIBs) formed by the virus were observed (Figures 1, 2).

The dimension of the PIBs was $2.03 \pm 0.25 \mu \mathrm{m}$. PIBs vary in size from 1.65 to $2.21 \mu \mathrm{m}$ and were usually irregular in shape. In electron microscopy studies, virions contained 1 to 8 nucleocapsids per virion (Figures 3,4$)$. The size of the viral particles was $366.67 \pm 54.72(312-500) \times 42.95 \pm 6.12(30-47) \mathrm{nm}$.

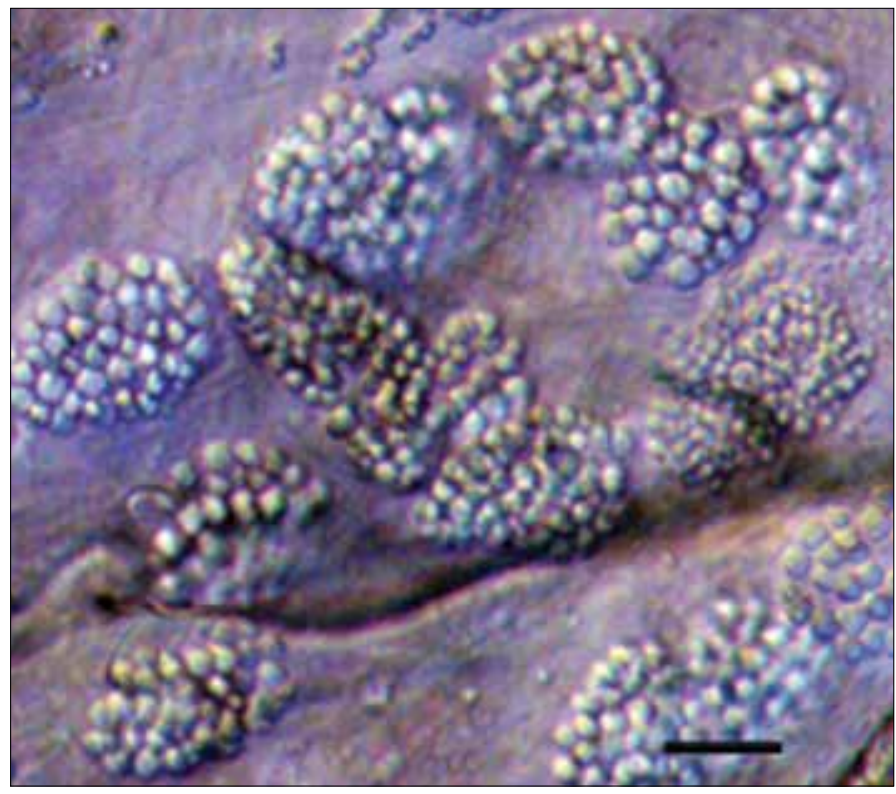

Figure 1. Polyhedra of Lymantria dispar nucleopolyhedravirus, light microscope (400x) bar $=25 \mu \mathrm{m}$

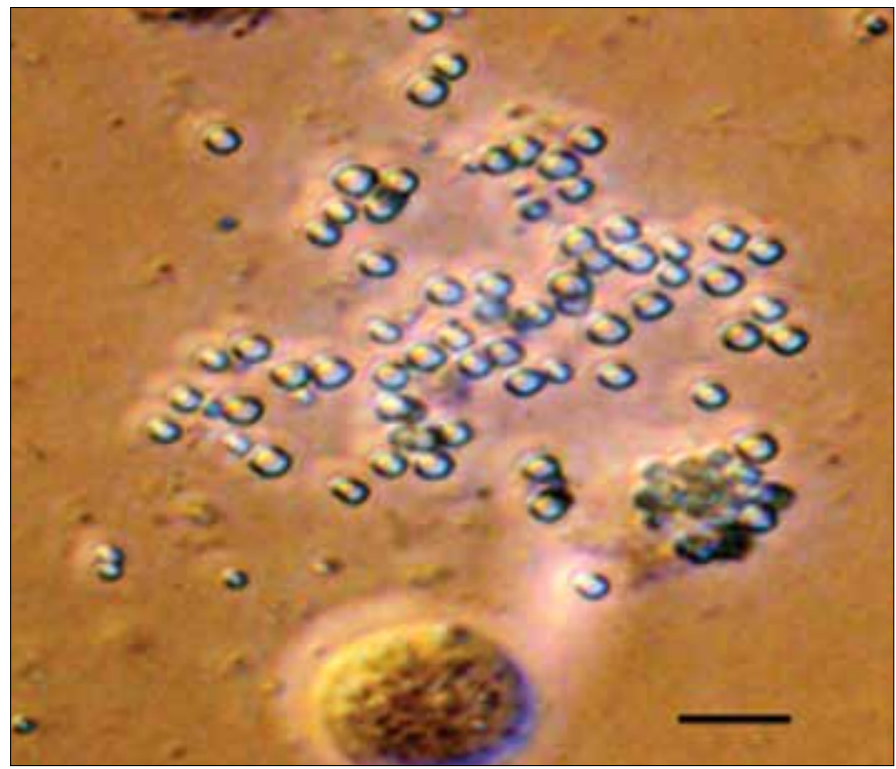

Figure 2. Polyhedra of Lymantria dispar nucleopolyhedravirus, light microscope (1000x) bar=10 $\mu \mathrm{m}$ 


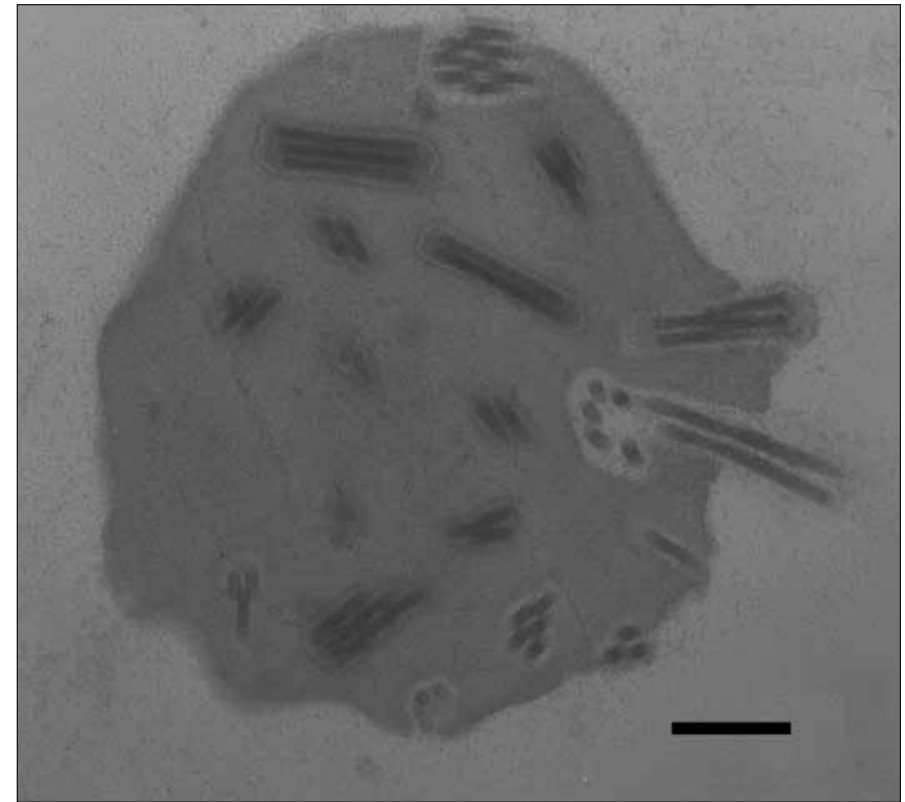

Figure 3. Section of a polyhedra with virions containing multiple rod-shaped nucleocapsids, note that some nucleocapsids and virions are leaving from PIB; bar $=250 \mathrm{~nm}$

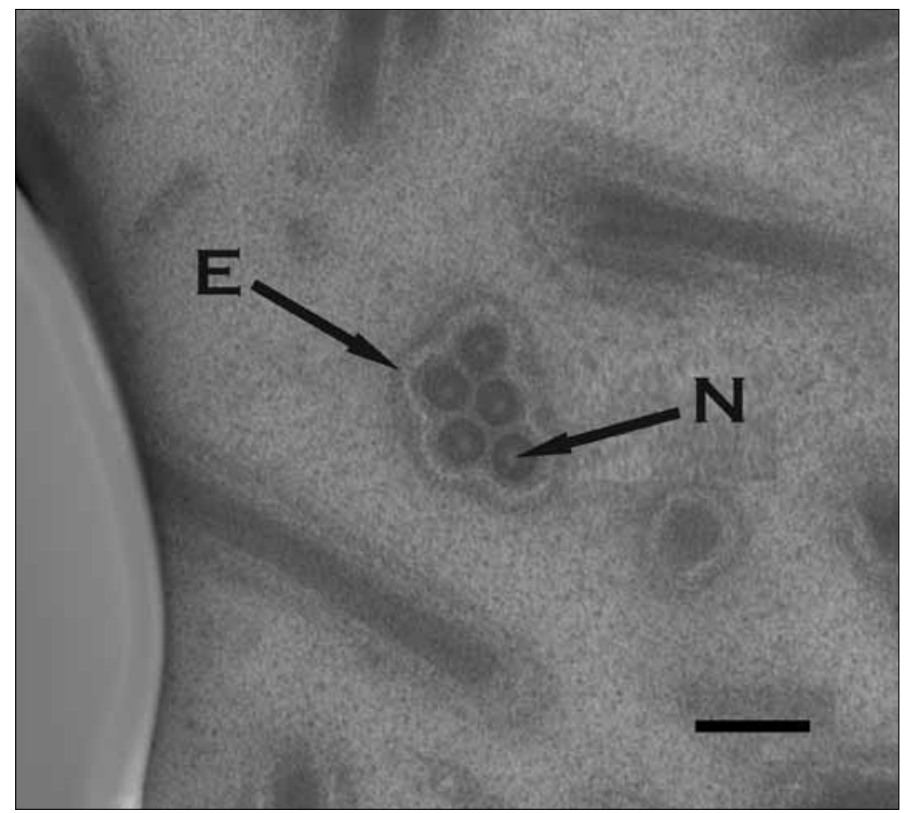

Figure 4. Cross section of virion including 5 nucleocapsid, (E) envelope and (N) nucleocapsid visible; bar $=100 \mathrm{~nm}$

\section{DISCUSSION}

In the literature, several different strains of LdMNPV were isolated from different parts of the world, such as the United States, Europe and Asia (11). These isolates have showed differences in both morphological features and insecticidal activities. Therefore, the scientists are stimulated to find a more effective strain of this virus for biological control of this insect pest. For this purpose, Narang et al. (1) compared three different strains of LdMNPV which were isolated from France (LdMNPVF), North America (a624) and Korea (LdMNPVK). According to that study; the average diameter of occlusion bodies (OBs) was 2.1 $\pm 0.06 \mu \mathrm{m}$ in LdMNPVF, $1.99 \pm 0.04 \mu \mathrm{m}$ in a624 and $1.5 \pm 0.06 \mu \mathrm{m}$ in LdMNPVK. In addition, the number of virions of $\mathrm{OBs}$ was $16.25 \pm 0.9$ in LdMNPVF, $16.2 \pm 1.39$ in LdMNPVK and $20 \pm 1.34$ in a624. On the other hand, in the Murillo et al. (2) study; some strains of nucleopolyhedrovirus obtained from different geographical areas showed different insecticidal activities. For instance, the LdMNPV strain from France was the least active, whereas the North American strain had the highest activity (1). Additionally, the Lymantria dispar multiple nucleopolyhedrovirus (LdMNPV) is a relatively virulent species. It pervades the tissues of the host and is usually lethal. It is currently being utilized as a biopesticide against the gypsy moth, Lymantria dispar. LdMNPV is the alternative control agent of environmentally sensitive areas because it only affects the gypsy moth (12). While there is considerable interest in the different isolates of LdMNPV in order to find a more effective strain, there is no record of natural isolation and characterization of this virus from Turkey. In this report, the isolation and characterization of a pure isolate of Lymantria dispar multinucleopolyhedrovirus (LdMNPV-TR) from Turkey is presented for the first time. The results show that the Turkish isolate of this virus presented here has different morphological characters. Therefore it may be one of the most infective strains. The idea that Asia is a potential source of new and interesting MNPV strains, proposed by Murillo et al. (2), supports our results.

\section{CONCLUSION}

The results of this study will encourage scientists to compare the infectivity and systematics of LdMNPV isolates from different parts of Europe and Asia at molecular levels, especially Turkish and other isolates, in order to find the most effective strain and understand their evolution.

\section{Conflict of Interest}

No conflict of interest was declared by the authors.

\section{REFERENCES}

1. Narang N, Herard F, Dougherty EM, Chen K, Vega FE. A gypsy moth (Lymantria dispar, Lepidoptera: Lymantriidae) multinucleocapsid nuclear polyhedrosis virus from France comparison with a North American and a Korean strain. Eur J Entomol 2001; 98: 189-94.

2. Murillo R, Munoz D, Lipa JJ, Cabellero P. Biochemical characterization of three nucleopolyhedrovirus isolates of Spodoptera exigua and Mamestra brassicae. J Appl Ent 2001; 125: 267-70.[CrossRef]

3. Yaman M. The first record of nucleopolyhedrovirus isolated from the satin moth Leucoma salicis L. (Lepidoptera, Lymantriidae) in Turkey. Folia Biol (Krakow) 2008; 56: 273-6.[CrossRef]

4. Hunter-Fujita RF, Entwistle PF, Evans HF, Crook NE. General laboratory practice. Hunter-Fujita RF, Entwistle PF, Evans HF, Crook $\mathrm{NE}$, editors. Insect Viruses and Pest Management. London: John Wiley \& Sons; 1998.p. 359-473.

5. Yaman M, Radek R. Nosema chaetocnema sp. n (Microspora: Nosematidae), a Microsporidian Parasite of Chaetocnema tibialis (Coleoptera: Chrysomelidae). Acta Protozool 2003; 42: 231-7.

6. Toguebaye BS, Marchand B, Bouix G. Microsporidia of Chrysomelidae. Petitpierre E, Hsiao TH, Jolivet PH, editors. Biology of Chrysomelidae. Boston: Kluwer Academic Publishers; 1988. p. 399-416.

7. Undeen AH, Vavra J. Research methods for entomopathogenic protozoa. Lacey L, editor. Manual of Techniques in Insect Pathology. 
Biological Techniques Series. London: Academic Press; 1997. p. 117-51.

8. Karnovsky MJ. Use of ferrocyanide-reduced osmium tetroxide in electron microscopy. 14th Ann Meet Am Soc Cell Biol: 1971. p. 146.

9. Spurr AR. A low-viscosity epoxy resin embedding medium for electron microscopy. Clin Microbiol Res 1969; 3: 197-218.

10. Reynold ES. The use of lead citrate at high $\mathrm{pH}$ as an electron-opaque stain in electron microscopy. J Cell Biol 1963; 17: 208-12.[CrossRef]
11. Shim HJ, Roh JY, Choi JY, Li MS, Woo SD, Oh HW, et al. Isolation and Characterization of a Lymantria dispar Multinucleocapsid Nucleopolyhedrovirus Isolate in Korea. The Journal of Microbiology 2003; 41: 306-11.

12. Slavicek JM. Temporal analysis and spatial mapping of Lymantria dispar nuclear polyhedrosis virüs transcripts and in vitro translation polypeptides. Virus Research 1991; 20: 223-36. [CrossRef] 